\title{
Rehabilitation model program for seriously ill patients
}

\begin{abstract}
BACKGROUND
Patients receiving cancer treatment start lifestyle changes mostly at the end of the treatment during the rehabilitation period. Most often, the first step is a dietary change and physical exercises built into the daily routine. Patients who do this in groups led by qualified therapists and based on professional counseling can build more effective and more permanent changes into their life.

To develop a complex rehabilitation program which, in the short term, aims to familiarize patients with a lifestyle which harmonizes the physical, mental, spiritual and social spheres of life and, in the long term, to build it into their everyday life in order to ameliorate the physical and mental state and reduce the psychological symptoms and the isolation of patients. The physical component focuses on diet and exercise. The psycho-social-spiritual support focuses on discovering inner sources of strength, developing active coping mechanisms and helping to achieve more open communication.
\end{abstract}

\section{PARTICIPANTS AND PROCEDURE}

In February and March 2011, 8 patients treated for malignant tumors participated in the model program. The components of the model program were psychotherapy, physiotherapy, cancer consultation, nutrition counseling, creative activities and walking.

\section{RESULTS}

During the period of the model program the isolation of the patients decreased and their social support and ability of coping with the illness ameliorated. They reported an ease in anxiety and depression in their everyday activities. According to feedback, their communication with each other, with the staff and with their relatives became more open. Altogether this had advantageous effects on the functioning of the ward and the mood of the staff.

\section{CONCLUSIONS}

The rehabilitation program confirmed that beside individual psycho-social support, beneficial and economic psycho-social support can be provided for the patients in group form along with the most effective assignment of the resources of the staff.

\section{KEY WORDS}

rehabilitation; oncology; psychotherapy; psycho-social support; psycho-oncology

ORganizations - 1: Urpion Kft., Budapest, Hungary · 2: Vaszary Kolos Hospital, Oncology Outpatient Clinic of Internal Medicine, Esztergom, Hungary · Semmelweis University, Faculty of Medicine, Institute of Behavioral Sciences, Budapest, Hungary

authors' contribution - A: Study design - B: Data collection - C: Statistical analysis - D: Data interpretation -

E: Manuscript preparation · F: Literature search · G: Funds collection

CORRESPONDing AUthor - Adrienne Kegye, Ph.D., Urpion Kft., Mária királyné útja 190, 1213 Budapest, Hungary, e-mail: kegyepalfi@t-online.hu

to Cite this ARTICle - Kegye, A., Pádi, É., \& Hegedűs, K. (2014). Rehabilitation model program for seriously ill patients.

Health Psychology Report, 2(4), 263-268. DOI: 10.5114/hpr.2014.45846 


\section{BACKGROUND}

In Hungary, one of the biggest burdens of illness for patients and their families is malignant tumor diseases. According to WHO data, Hungary leads cancer statistics in Europe. There are 70000 new cancer cases per 10 million inhabitants/year and cancer mortality is $32000 /$ year. Cancer is the second major cause of death after cardiovascular diseases (Hegedűs, 2012). Approximately one in three families is affected by cancer diseases and related psycho-social burdens as well as coping and adaptation difficulties.

From the point of view of patients it is essential that they can preserve their quality of life and their independence, and remain useful and active members of the family, the workplace and in a wider sense the community and society. This is what oncological rehabilitation, which accompanies the patient from disease detection during the entire course of the disease, can offer them (Riskó, 2006a). The exact definition of rehabilitation is laid down in article 100 of the Health Act, which states that rehabilitation is organized support provided by society to impaired persons who suffer temporary or permanent damage to health, or physical or mental integrity, so that they can regain their place in the community by using restored or remaining abilities.

Correspondingly, the law lays down that the aim of medical rehabilitation is to help integration and reintegration into everyday life with health science instruments as well as with the development or supplement of existing abilities. It considers that physiotherapy, sport therapy, psychological services and employment therapy are integral parts of medical rehabilitation. It highlights that the application should be methodical, collective, aligned and personalized with the active participation of the patient. Considering the place and necessity of rehabilitation and psychosocial support in oncological attendance, the following literary data deserve attention.

According to estimations made by Hawkes et al. (2009), a significant proportion of patients were not aware of the criteria of healthy lifestyle and health behavior. Meanwhile, distress was observed in $40 \%$ of colorectal cancer survivors, which was more serious in smoking, physically inactive and overweight patients. In the first 12 months following the diagnosis, $60 \%$ of colorectal cancer survivors are overweight, $70 \%$ are not sufficiently active and in $22 \%$ there is a high risk of development of alcoholism. At the same time research shows that those who boost their physical activity report a better quality of life, as well as less anxiety and depression.

Hann, Baker, Denniston, and Entrekin (2005) examined the application of supplementary therapies/ methods in long surviving breast cancer patients. Most of them reported that using them helps to cope with stress, to sustain hope, to hope for diminishing recurrence and to have an active role in the healing process. The most generally used supplementary therapies were physical exercise, vitamins, prayer or spiritual exercises, humor, self-help books, and relaxation.

We often see that cancer patients start lifestyle changes already at the beginning of the illness, although it is more characteristic at the end of the treatment during the period of rehabilitation. The pattern is very similar. Most often, first, there is a dietary change which is followed by physical exercises included in the daily routine. The components of cancer rehabilitation are physiotherapy, psychosocial support, dietetics, medical aids and logopedics, which are not only related to each other but also strengthen the benefits of each other (Riskó, 2006a). Those patients who make changes based on professional counseling and mental support and guidance of qualified therapists (dietitians, physical therapists, psychotherapists, oncologists) in groups can more efficiently and permanently build them into their own life and the life of their family (Riskó, 2006a).

These experiences led us to develop a psycho-educational and supportive rehabilitation program for cancer patients finishing active treatment at the Oncological Rehabilitation and Hospice Ward of the Vaszary Kolos Hospital in Esztergom. The objective in the short term was to familiarize patients with a lifestyle harmonizing the physical, mental, spiritual, and social spheres, and in the long term to build them into everyday life in order to ameliorate physical and mental wellbeing and diminish psychological symptoms and isolation. The physical component focused on diet and exercise while psycho-social-spiritual support focused on discovering inner sources of strength, developing active coping mechanisms and helping to achieve more open communication.

\section{PARTICIPANTS AND PROCEDURE}

We planned the program for groups; it consists of the following elements: psychotherapy based on the psychoanalytical method, creative activities, physiotherapy, active exercise individually and in groups, dietetic counseling and cancer counseling. Entering/ leaving the fast-rotating open group was determined by the hospital's patient traffic and the average residence time of patients (Szőnyi, 2005).

The advised period for participating in the program was 3 weeks. There were physical exercises and creative activities on a daily basis. Physical exercises took the form of physiotherapy three times a week and individual walking every day. The suggested duration of the latter was 30 minutes/day. Group psychotherapy took place twice a week for 50 minutes 
Table 1

Weekly schedule plan of the rehabilitation model program

\begin{tabular}{|c|c|c|c|c|c|}
\hline & Monday & Tuesday & Wednesday & Thursday & Friday \\
\hline $8.00-9.00$ & breakfast & breakfast & breakfast & breakfast & breakfast \\
\hline $9.00-10.00$ & walking & walking - activity & walking & walking - activity & walking \\
\hline $10.00-10.50$ & & $\begin{array}{l}\text { psychotherapy } \\
\text { group }\end{array}$ & & $\begin{array}{l}\text { psychotherapy } \\
\text { group }\end{array}$ & \\
\hline $11.00-12.00$ & free time & free time & free time & free time & free time \\
\hline $12.00-12.30$ & physiotherapy & & physiotherapy & & physiotherapy \\
\hline $12.30-14.00$ & lunch + retreat & lunch + retreat & lunch + retreat & lunch + retreat & lunch + retreat \\
\hline $14.00-14.45$ & activity & activity & $\begin{array}{c}\text { oncological group } \\
\text { consultation }\end{array}$ & activity & \\
\hline $15.00-16.00$ & & & dietetics & & \\
\hline After 16.00 & $\begin{array}{l}\text { half hour walk } \\
\text { recommended }\end{array}$ & $\begin{array}{l}\text { half hour walk } \\
\text { recommended }\end{array}$ & $\begin{array}{l}\text { half hour walk } \\
\text { recommended }\end{array}$ & $\begin{array}{l}\text { half hour walk } \\
\text { recommended }\end{array}$ & $\begin{array}{l}\text { half hour walk } \\
\text { recommended }\end{array}$ \\
\hline
\end{tabular}

each occasion. On these days creative activity was organized as a preparatory group activity for psychotherapy, while on other days it was an afternoon occupation. We planned cancer consultation and dietetic counseling to take place once a week. For the weekly schedule see Table 1 .

Those patients who did not get into the model program could come in for psychosocial support $2 \times 30 \mathrm{~min}-$ utes weekly.

During admission to the ward, patients filled in a pre-screening questionnaire and participated in the first interview. The questionnaire was developed by the staff of the Szent László Hospital's Cancer Center (Budapest) for the pre-screening of cancer patients' psychosocial state. We got the opportunity to use this in our work. The questionnaire was used to assess general psychosocial state, coping, and the level of social support, depression, and anxiety. Based on the recommendation of the oncologist, the psychosocial results and the individual needs of the patients, the team decided together whether to participate in the rehabilitation program or get individual psychological support.

On the third day of the rehabilitation program, hospice patients receiving palliative care asked to join the group. While the focus of therapy in the case of the originally planned rehabilitation was reintegration into social life, family and work, in palliative care the emphasis was put on processing difficulties and problems concerning the end of life and dying. Correspondingly, we had to form a different psychotherapy group for hospice patients; an article has been published about the latter (Kegye \& Pádi, 2013). The basic objectives of the program remained the same in each patient group. Patients participated together in creative activities and exercises.

\section{RESULTS}

The model program took place in 2011. In February and March the pre-screening questionnaire was filled in by 8 patients: 3 men and 5 women. Their average age was 65 years. Seven of them were pensioners, and 1 of them received a disability pension. The distribution of tumors based on location was as follows: colon - 3; pancreas, cervix, stomach, lung - 1 person each; 1 person had an unknown primary tumor. There was no metastasis in any of the cases. Patients participating in the rehabilitation program were asymptomatic, they participated in regular cancer care and their life expectancy was longer than 1 year.

The items of the HADS (Hospital Anxiety and Depression Scale) (Muszbek et al., 2006) measuring depression were in the normal range and they showed severe depression in the case of one person. Items related to anxiety were in the normal range in 6 cases and showed moderate anxiety in 2 cases. In the first interview, when describing their problems, patients put anxiety in the first place. When measuring depression and anxiety, we found moderate anxiety in the case of 2 patients and severe depressive symptoms in 1 case; in this case administering medication was necessary. We ensured the possibility of individual therapy for those participating in group therapy; this possibility was used once in the rehabilitation group.

Physical exercise and nutrition was chosen by 5 patients in the first place when they had to give data on coping. Relaxation, meditation and individual or group psychological counseling were put in the second place with 2 marks. The self-help patient group was given 1 mark and pastoral help, alternative medicine and other possibilities were not
Rehabilitation model program for seriously ill patients 
Adrienne Kegye,

Éva Pádi,

Katalin Hegedús marked at all. Social and group coping possibilities outside the home were used only in very few cases. They did not feel that help was necessary in everyday life. One person chose pastoral help and 7 answered "no" to this question. To the question whether they would choose the help of a psychologist, 2 patients answered "yes", 4 of them "maybe", and 1 "no"; 1 patient did not answer this question.

Compared to the total score (36) of the Caldwell social support scale (Caldwell, Pearson, \& Chin, 1987; Kopp \& Kovács, 2006), values given by the patients were very low. We found low social support (less than 10 points) for 6 patients. It was very low, 3 points or lower, for 2 patients and we found a value between 10 and 15 for 2 patients. In the questionnaire, there were 5 items concerning the family and 7 items concerning social support outside the family; their total score was 15 and 21. All of the 8 patients marked family support; its median value was 6 . Social support outside the family (such as friends, colleagues, neighbors, helping professionals in 2 cases) was marked by 5 patients; its median value was 2 .

Isolation and limitation in the scope of the patients' activity and communication can be generally detected during their hospital care. They spend most of their time in the hospital bed, they do not leave the ward; they mostly speak with the staff or their roommates or in the short time when their relatives visit them. Most often, their activities consist of solving crosswords, watching TV or having a short walk on the balcony.

The analysis of the questionnaires refers to the same. The social support of the patients is low. All of the patients marked their family members, mostly their spouses and their children, but the total value of family support, $6 / 15$, is low. The value of other social support is even lower: $2 / 21$ and $27 \%$ of the patients do not receive any. These data refer to the increased isolation of the patients. This tendency is strengthened by the fact that the patients barely do social activities which can help with coping. Six patients marked less than 3 from the 8 possible items of the questionnaire and in the first interviews they reported that they practice dietary changes and exercises in the family. These data show that patients who filled in the questionnaire are rather passive in coping with the illness.

We planned creative activities and physiotherapy to solve these problems, which we already assumed would appear while developing the program. Psychotherapeutic activities were preceded by mandala coloring. Mandalas are tools for meditation that have been used for thousands of years. We chose them for their capacity for helping relaxation and attunement to the problem and to each other, to express feelings through colors and forms, for their wide possibility of choice, and not least for their low costs. Afternoon group chats, as well as group and manual arts ac- tivities, were aimed at enhancing activity, reviving forgotten activities (e.g., games), enhancing social support and decreasing isolation. We considered physiotherapy as an important element because of the favorable effects of exercise on wellbeing, body image, keeping active and stress relief; we tried to build it into the program in the form of individual and group walking so that patients could acquire it and include it in their daily schedule (Kegye \& Pádi, 2013).

The aims such as reducing psychological symptoms, formulating active coping mechanisms, helping communication, and decreasing isolation, which were projected in the planning phase of the program, harmonized well with individual aims formulated and observed during the patients' psycho-diagnostic examination; hence all of them accepted the possibility of participating in the program after the first interviews.

Patients participated in the rehabilitation model program for an average of 2.50 weeks, this period consisting of an average of 5 psychotherapeutic sessions.

In the focus of psychotherapeutic sessions, there were thoughts and feelings of the patients concerning illness, loss, their family, their life expectancy, their activities and objectives.

During regular doctor's visits and group sessions, patients reported the easing of their anxiety and the remission of their depression, and this was perceptible in their everyday activities. Their communication with each other, with the staff of the ward and, as feedback proved, with their relatives became more open. After an initial closed period, patients participated in creative activities more and more voluntarily, openly and actively. They brought home drawings and objects they created as presents for their family members.

\section{DISCUSSION}

Unfortunately, the program had to be discontinued at the end of March 2011 due to low patient traffic and organizational and personnel changes at the ward. Due to the shortness of time, the cancer centers of the region could not become acquainted with the program, so patients came only from the hospital's cancer clinic. Thus, only a few patients could participate in the program, which can therefore be considered as a model program although the aim was to introduce it more widely.

Measuring the effectiveness of the program and the follow-up of patients was difficult because of the shortness of the program and the low number of patients. In the future, when starting similar programs, it is worth placing more emphasis on measurement of effectiveness. Nevertheless, during this short time the rehabilitation program was met with positive 
responses. We experienced recognizable changes concerning both patients and staff. Members of the professional staff still talk about their memories and say that they miss the program (Kegye \& Pádi, 2013).

The pre-monitoring questionnaire and the first interview made possible the assessment of the patients' psychosocial state and their individual aims so group work could be individually developed and flexibly adapted to the patients' situation, which is one of the most important criteria of rehabilitation (Riskó, 2006a).

In terms of the number of participants in the program the group was small, and in terms of its duration it was short, which however in alignment with literature data (Szőnyi, 2005; Beutel, Veissflog, \& Leuteritz, 2014; Sherman, Heard, \& Cavanagh, 2010) offered the possibility to everyone to make personal manifestations and statements and to give honest and helping attention to each other. Short group sessions helped patients to be able to discuss the actual difficulties and tensions in their lives and in their non-adaptive coping strategies.

We found that the analytically oriented psychotherapeutic method was sufficient because by inciting the expression of feelings through thoughts, memories and behavior, it efficiently helped adaptation, cooperation, coping with the illness and fears, handling anxiety and mood problems, strengthening the self, and opening up communication, thus avoiding isolation (Szőnyi, 2005; Riskó, 2006b).

In the psychotherapeutic work of the group we observed the following factors summarized in Yalom's work (Yalom, 2001): universality, altruism, imitating behavior, group cohesion, catharsis, hope, interpersonal learning about relationships and existential factors. Fellow patients can serve as a model in coping; they give information, understand each other at the level of experiences and share their feelings (Payne, Vroom, \& Phil, 2009; Riskó, 1999).

Participating in groups ameliorates adaptation and develops social relationships. The consequent good mood and relationships can enhance self-confidence and radiate to other persons or the environment (Riskó, 2006b).

During group psychotherapy, participants found that their anxiety was relieved due to more open communication. During therapeutic sessions and later in the ward, they could experience an ease in isolation due to building up contacts and being engaged in social activities, and more open communication was beneficial in their family relationships, too. We could experience the program's positive effects on the environment. Patients who could not participate in the program could nevertheless participate in creative, social activities. Some of them were happy to color mandalas, while others participated in afternoon activities, conversations or walks (Kegye \& Pádi, 2013).
Cancer consultation and dietetic counseling planned to take place once a week could not be realized in a group, only individually, considering individual needs, due to the small number and the work overload of doctors and the hospital's dietetic service.

The examination and treatment of malignant tumors is very stressful for patients both physically and mentally; hence rehabilitation is also two-fold: physical and mental. In a narrower sense, rehabilitation begins after the completion of treatment, but during the course of the disease every cancer patient could need it in some form. (Riskó, 1999; Cherrier, 2013).

Paradoxically, one of the most significant results of the rehabilitation program is the justification of the above statement or the confirmation of the idea which is unusual in the current national oncological practice - that patients need psychosocial support in a group as well as individually during the palliative period, particularly in the beginning when their general physical state makes it possible! This is well demonstrated by the fact that by the time the rehabilitation group had been launched, patients receiving palliative care indicated that they would also like to participate in the program. This situation, having regard to the fact that the central problems are different in the different phases of the course of the illness, made necessary the expansion according to the needs of the patients of the palliative group.

Among the beneficial effects of the program, it is important to emphasize the economic benefits. It was feasible with the available, small-number, heavily loaded staff, and it also proved to be time and cost-effective. Group physiotherapy assured a professionally guided possibility of doing exercise for more patients in a shorter time. Group psychotherapeutic sessions made it possible for more patients to receive psychosocial support without changing the number of participants or the duration of the sessions (Kegye \& Pádi, 2013).

This program, which consists of the elements of a complex support system, showed that working in groups provides beneficial, efficient rehabilitative care along with the most effective division of the staff's resources.

\section{REFERENCES}

Beutel, M. E., Veissflog, G., \& Leuteritz, K. (2014). Efficacy of short-term psychodynamic psychotherapy (STPP) with depressed breast cancer patients: results of a randomized controlled multicenter trial. Annals of Oncology, 25, 378-384.

Caldwell, R. A., Pearson, J. L., \& Chin, R. J. (1987). Stress moderating effects: Social support in the context of gender and locus of control. Personality and Social Psychology Bulletin, 13, 5-17.
Rehabilitation model program for seriously ill patients 
Adrienne Kegye,

Éva Pádi,

Katalin Hegedús
Cherrier, M. M., Anderson, K., David, D., Higano, C. S., Gray, H., Church, A., \& Willis, S. L. (2013). A randomized trial of cognitive rehabilitation in cancer survivors. Life Sciences, 93, 617-622.

Hann, D., Baker, F., Denniston, M., \& Entrekin, N. (2005). Long-term Breast Cancer Survivors' Use of Complementary Therapies: Perceived Impact on Recovery and Prevention of Recurrence. Integrative Cancer Therapies, 4, 14-20.

Hawkes, A. L., Pankenham, K. I., Courneya, K. S., Gollschewski, S., Baade, P., Gordon, L. G., Lynch, B. M., Aitken, J. F., \& Chambers, S. K. (2009). A randomised controlled trial of a tele-based lifestyle intervention for colorectal cancer survivors ('CanChange'): study protocol. BMC Cancer, 9, 286.

Hegedűs, K. (2012). Rozwój psychoonkologii na Węgrzech - stan obecny i zadania [The development of psychooncology in Hungary - current status and tasks]. Psychoonkologia, 16, 17-19.

Kegye, A., \& Pádi, É. (2013). A csoport-pszichoterápia lehetősége a hospice-palliatív ellátásban [The possibility of group psychotherapy in hospice-palliative care]. Orvosi Hetilap, 154, 1102-1105.

Kopp, M., \& Kovács, M. (2006). Appendix: Questionnaires used in the Hungarostudy 2002 survey. In: M. Kopp, \& M. Kovács. A magyar népesség életminősége az ezredfordulón [The quality of life of the Hungarian population at the turning of the century] (pp. 540-550). Semmelweis.

Muszbek, K., Székely, A., Balogh, M., Molnár, M., Rohánszky, M., Ruzsa, A., Varga, K., Szöllosi, M., \& Vadász, P. (2006). Validation of the Hungarian translation of Hospital Anxiety and Depression Scale. Quality of Life Research, 15, 761-766.

Payne, D. K., Vroom, P., \& Phil, M. (2009). Supportive group psychotherapy: a group intervention for cancer patients. Memorial Sloan-Kettering Cancer Center: New York.

Riskó, Á. (ed.). (1999). A test, a lélek és a daganat [The body, the soul and the tumor] (pp. 82-90). Budapest: Animula.

Riskó, Á. (2006a). A pszichoszociális rehabilitáció [Psychosocial rehabilitation]. In: J. Horti, \& Á. Riskó (eds.), Onkopszichológia a gyakorlatban [Onco-psychology in practice] (pp. 258-269). Budapest: Medicina.

Riskó, Á. (2006b). Csoport-pszichoterápia [Group psychoterapy]. In: J. Horti, \& Á. Riskó (eds.), Onkopszichológia a gyakorlatban [Oncopsychology in practice] (pp. 269-277). Budapest: Medicina.

Sherman, K. A., Heard, G., \& Cavanagh, K. L. (2010). Psychological effects and mediators of a group multi-component program for breast cancer survivors. Journal of Behavioral Medicine, 33, 378-391.

Szőnyi, G. (ed.). (2005). Csoportok és csoportozók [Groups and participants] (p. 119). Budapest: Medicina.
Yalom, I. D. (2001). Terápiás tényezők-egységesen [Therapeutic factors on the basis of the same principle]. In: I. D. Yalom (ed.), A csoportpszichoterápia elmélete és gyakorlata [Group psyhotherapy in theory and pracice] (pp. 67-95). Budapest: Animula. 